\title{
The characteristics of automobile catalyst-derived platinum group elements in road dusts and roadside soils: a case study in the Pearl River Delta region, South China
}

\author{
Liang Qi $\cdot$ Mei-Fu Zhou $\cdot$ Zheng Zhao • \\ Jing $\mathbf{H u} \cdot$ Yan Huang
}

Received: 5 October 2009/ Accepted: 21 June 2010/Published online: 13 July 2010

(C) The Author(s) 2010. This article is published with open access at Springerlink.com

\begin{abstract}
The emission of platinum group elements (PGE) from automobile catalytic converters has led to enrichment of PGE in road dusts and roadside soils in urban areas that are well above the natural background levels. This paper evaluates the source of contamination of all the PGE and Au in road dusts and roadside soils in the Pearl River Delta region, including three major cities, Shenzhen, Guangzhou and Hong Kong, South China. Samples were digested using Carius tube and analyzed by isotope dilution ICP-MS; Os was separated by distillation and other PGE by Te-coprecipitation. All samples have elevated PGE concentrations above the background values of uncontaminated soils and contain higher $\mathrm{Pt}, \mathrm{Pd}$ and $\mathrm{Rh}$ than other PGE. The maximum values are $181 \mathrm{ng} / \mathrm{g} \mathrm{Pt}$, 514 ng/g Pd, 53 ng/g Rh and 1345 ng/g Au. There are clear positive correlations between $\mathrm{Pt}$ and $\mathrm{Pd}, \mathrm{Pt}$ and $\mathrm{Rh}$, and $\mathrm{Pd}$ and $\mathrm{Rh}$, indicating that the main emitted of PGE from automobile catalyst are $\mathrm{Pt}, \mathrm{Pd}$ and $\mathrm{Rh}$. High concentrations of $\mathrm{Au}$ were also found in road dust samples from Hong Kong and Shenzhen. Dust samples with higher Os contents have lower ${ }^{187} \mathrm{Os} /{ }^{188} \mathrm{Os}$ ratios. Samples from Hong Kong show relatively high $\mathrm{Pt} / \mathrm{Rh}$ ratios. Positive correlations between Pt and $\mathrm{Ru}$, and Pt and Ir were found in Shenzhen and Hong Kong, but only positive correlations between $\mathrm{Pt}$ and Ir were found in Guangzhou. These different
\end{abstract}

L. Qi $(\bowtie) \cdot$ Z. Zhao $\cdot$ J. Hu $\cdot$ Y. Huang

State Key Lab of Ore Deposit Geochemistry,

Institute of Geochemistry, Chinese Academy of Sciences,

Guiyang 550002, China

e-mail: qilianghku@hotmail.com

M.-F. Zhou

Department of Earth Sciences, The University of Hong Kong,

Pokfulam Road, Hong Kong, China characteristics reflect different automobile catalytic systems used in Hong Kong and mainland China.

Keywords Automobile catalyst - PGE - Road dust . Roadside soil $\cdot$ South China

\section{Introduction}

Most modern vehicles are fitted with a three-way catalytic converter that uses platinum group elements (PGE) (mostly, Pt, Pd and Rh) as catalysts to minimize toxic gas emissions produced during gas combustion. Catalysts remove about $90 \%$ of total carbon monoxide, unburned hydrocarbons, and nitrogen oxides $\left(\mathrm{NO}_{x}\right)$ from exhausts and transform these pollutants to more innocuous carbon dioxide, nitrogen, and water (Barefoot 1997). However, PGE are emitted both in nanometer and micrometer particles on the surfaces of road dusts, roadside soils and plants during vehicle operation as evidenced by atmospheric particle analysis (Palacios et al. 2000; Hooda et al. 2007; Cicchella et al. 2008). The emission rates of Pt as high as $800 \mathrm{ng} / \mathrm{km}$ depend on speed, vehicle condition and exhausting temperatures (Moldovan et al. 2002). Although emission rates of PGE are relatively low, an estimated 500 million vehicles worldwide are equipped with catalysts (Barbante et al. 2001), resulted in increasing interest in their environmental behavior worldwide in the recent past. PGE contamination from vehicle emission is in metallic and oxide forms. They may be soluble, transported by water, deposited in sediments and soils, eventually they may enter the food chain and the living organisms. High levels of PGE in human body may cause asthma, nausea, hair loss, abortion, dermatitis and other health problems (Ravindra et al. 2004). Previous studies have found 
elevated PGE levels in urban airborne dusts (e.g. Rauch et al. 2005; Wichmann et al. 2007), road dusts and roadside soils (e.g. Lesniewska et al. 2004; Morcelli et al. 2005; Hooda et al. 2007; Cicchella et al. 2008), sediments (e.g. Rauch et al. 2004a; Whiteley and Murray 2005), and roadside vegetation (e.g. Zechmeister et al. 2006; Hooda et al. 2008). Bioaccumulation of PGE contaminants in aquatic (e.g. Zimmermann et al. 2004, 2005; Sures and Zimmermann 2007) and internal organs of birds has also been extensively studied (e.g. Jensen et al. 2002; Ek et al. 2004).

Automobile catalytic converters were introduced to China in 1993. As the biggest developing country in the world, the number of vehicles in China increases annually, with addition of about 7 million new vehicles each year in the recent past, and 10 million new vehicles in coming years. The rapid increase of vehicles equipped with catalysts may pose a problem of PGE contamination in urban areas. Thus, monitoring PGE contamination is important in populated regions, such as the Pearl River Delta region, South China. Although numerous studies of PGE contamination have been carried out in other countries, only a few similar studies with limited data have been reported in China (Kan and Tanner 2004; Fang et al. 2005; Kan and Tanner 2005; Wang and Qin 2007; Wang et al. 2005, 2007; Wang and Sun 2009; Pan et al. 2009). The aim of this study is to evaluate PGE contamination in road dusts and roadside soils by comparing with uncontaminated soils collected from three major cities, Shenzhen, Guangzhou, and Hong Kong in the Pearl River Delta region. A comparison is made for the PGE dataset between Hong Kong and mainland China that have different automobile catalyst systems.

\section{Methodology}

General information and sample collection

The Pearl River Delta region is one of the most populated areas in China (Fig. 1). Three major cities, Guangzhou, Shenzhen and Hong Kong, have populations of about 10, 9 and 7 million, respectively. They have registered vehicles of about 1,1 and 0.6 million, respectively. All automobiles in Hong Kong are imported from overseas, but most of automobiles in Guangzhou and Shenzhen are made in China.

The sampling strategy was designed to ensure a representative coverage of areas of high traffic densities with no industrial input, i.e. the downtown road and its main intersections, as well as uncontaminated soils (Table 1). Sample collection was carried out in 2007 and 2008 during winter and spring time, approximately 2 weeks after the

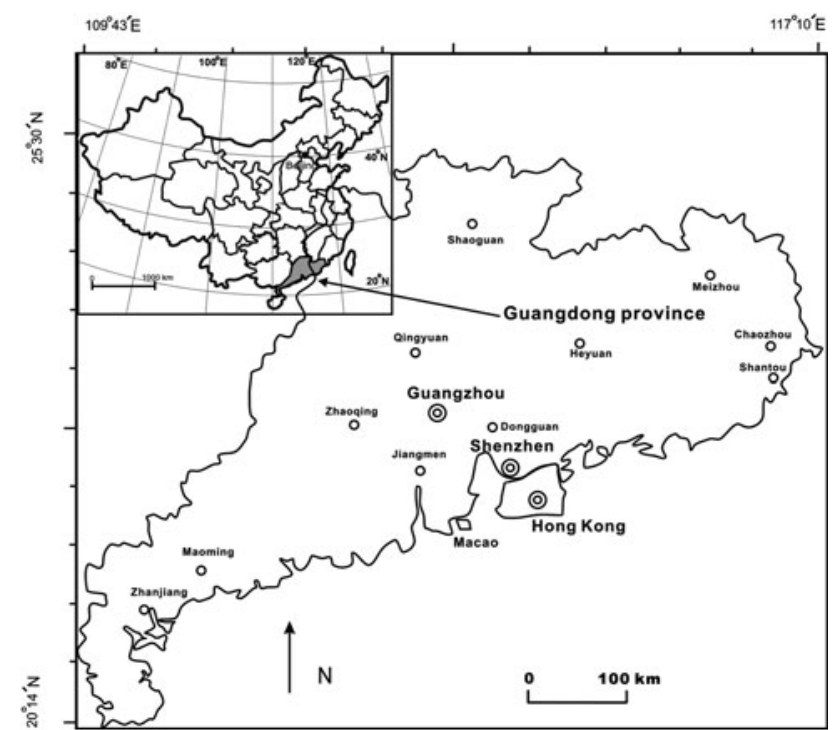

Fig. 1 Geographic location of Pearl River Delta region, South China

last rain. Road dust samples were hand-brushed and collected from the main street edge and the intersections located in the center of the city. Roadside soil samples were collected from the soil layer (about $5 \mathrm{~mm}$ thickness) of gardens along the main street about $3 \mathrm{~m}$ away from the street edge. Uncontaminated soil samples were collected from areas at least $200 \mathrm{~m}$ away from traffic and may represent samples with natural PGE background values.

The collected samples were dried for $12 \mathrm{~h}$ at $105^{\circ} \mathrm{C}$, homogenized and sieved to particle sizes of 150 mesh with a plastic sieve and stored in polypropylene bottles at room temperature for analysis.

Instrumentation and reagents

The instrument used in this study is an ELAN DRC-e ICPMS in the State Key Lab of Ore Deposit Geochemistry, Institute of Geochemistry, Chinese Academy of Sciences, Guiyang. The sensitivity of the instrument was adjusted to $>40,000 \mathrm{cps}$ for $1 \mathrm{ng} / \mathrm{ml}$ of ${ }^{115} \mathrm{In}$.

$\mathrm{HCl}$ and $\mathrm{HNO}_{3}$ were purified by sub-boiling distillation. Water was obtained from $18 \mathrm{M} \Omega \mathrm{cm}$ grade Millipore purification system. Te solution (about $2 \mathrm{mg} / \mathrm{ml}$ ) and $\mathrm{SnCl}_{2}$ solution $(20 \%, \mathrm{w} / \mathrm{v})$ were purified by Te-coprecipitation (Qi et al. 2004). The Carius tubes and Os distillation system are same as that described by Qi and Zhou (2008). Spike solutions with enriched stable isotopes, ${ }^{194} \mathrm{Pt},{ }^{105} \mathrm{Pd}$, ${ }^{101} \mathrm{Ru},{ }^{193} \mathrm{Ir}$, and ${ }^{190} \mathrm{Os}$, were prepared from pure metals (US Services Inc., Oxbow, NJ). An ICP multi-element standard solution of $100 \mu \mathrm{g} / \mathrm{ml}$ of Pt, Pd, Rh, Ru, Ir, and $\mathrm{Au}$ (AccuStandard, USA) was used and diluted as needed for calibrating the spike solutions and the concentrations of mono-isotopic element, $\mathrm{Rh}$ and $\mathrm{Au}$. 
Table 1 Sampling sites and their characteristics

\begin{tabular}{cll}
\hline Samples & Sample type & Sampling sites and characteristics \\
\hline Hong Kong & & \\
HKD-1-4 & Dust & Des Voeux RD West, high traffic density \\
HKD-5-9 & Dust & Central, high traffic density \\
HKD-10-12 & Dust & Wan Chai, high traffic density \\
HKFS-1-3 & Soil & Long Fu Shan country park, uncontaminated soil \\
HKS-1-3 & Soil & Des Voeux RD West, high traffic density \\
HKS-4-7 & Soil & Central, high traffic density \\
HKS-8-9 & Soil & Wan Chai, high traffic density \\
Shenzhen & & \\
SZD-1-4 & Dust & Luohu district, Binhe RD, high traffic density \\
SZD-5-8 & Dust & Futian district, Fuming RD, high traffic density \\
SZD-9-12 & Dust & Nanshan district, Shennan RD, high traffic density \\
SZFS-1-2 & Soil & Renming Park, uncontaminated soil \\
SZS-1-2 & Soil & Luohu district, Binhe RD, high traffic density \\
SZS-3-5 & Soil & Futian district, Fuming RD, high traffic density \\
SZS-6-8 & Soil & Nanshan district, Shennan RD, high traffic density \\
Guangzhou & & Tianhe district, Guangyuan RD east, high traffic density \\
GZD-1-3 & Dust & Tianhe district, Linhe RD, high traffic density \\
GZD-4-6 & Dust & Baiyun district, Jichuang RD, high traffic density \\
GZD-7-10 & Dust & Baiyun mountain, uncontaminated soil \\
GZFS-1-2 & Soil & Tianhe district, Guangyuan RD east, high traffic density \\
GZS-1-2 & Soil & Soil \\
GZS-3-5 & Soil & \\
GZS-6-8 & & Tianhe district, Jichuang RD, high traffic density \\
\hline
\end{tabular}

\section{Analytical procedure}

In this study, powdered samples $(5,000 \mathrm{~g}$ for road dust, $10,000 \mathrm{~g}$ for roadside soil and uncontaminated soil) were accurately weighted and ignited in a porcelain crucible at $650^{\circ} \mathrm{C}$ to remove the organic materials, and then transferred to a $75 \mathrm{ml}$ Carius tube. Appropriate amount of enriched isotope spike solution containing ${ }^{194} \mathrm{Pt},{ }^{105} \mathrm{Pd}$, ${ }^{101} \mathrm{Ru},{ }^{193} \mathrm{Ir}$, and ${ }^{190} \mathrm{Os}$ was accurately added and mixed with $15-30 \mathrm{ml}$ aqua regia depending on the sample mass. The sealed Carius tube was placed in a custom-made high-pressure autoclave filled with water to prevent explosion of the tube when heated to about $250^{\circ} \mathrm{C}$ (Qi and Zhou 2008). After $10 \mathrm{~h}$, the Carius tube was cooled and the contents were transferred to a 50-ml centrifuge tube. After centrifuging, the upper solution was transferred to a distillation system for Os distillation. The collected Os solution was used for measuring the Os concentration by isotope dilution and the ratios of ${ }^{187} \mathrm{Os} /{ }^{188} \mathrm{Os}$. After distillation, the remaining solution was used to pre-concentrate PGE by Te-coprecipitation and all the interference elements are removed using a cation exchange resin and P507 extraction chromatography resin combined in the same column (Qi et al. 2004). Platinum, Pd, Ru, and Ir were measured by isotope dilution, whilst ${ }^{194} \mathrm{Pt}$ was used as the internal standard to calculate the concentration of the mono-isotope elements $\mathrm{Rh}$ and Au. The total procedural blanks were lower than $0.0003 \mathrm{ng} / \mathrm{g}$ for Os, $0.003 \mathrm{ng} / \mathrm{g}$ for $\mathrm{Ru}, \mathrm{Rh}$ and $\mathrm{Ir}, 0.04 \mathrm{ng} / \mathrm{g}$ for $\mathrm{Pd}$, and $0.02 \mathrm{ng} / \mathrm{g}$ for Pt (Table 2).

\section{Quality control}

An urban dust reference material, BCR-723 (0.5 g), was used for quality control in this study and digested both directly and after ignition at $650^{\circ} \mathrm{C}$ to investigate the loss of PGE during this process. Analytical results are shown in Table 2. The results for direct digestion and after ignition agree well, indicating no lost of PGE during the ignition treatment. The results of $\mathrm{Pt}, \mathrm{Pd}$ and $\mathrm{Rh}$ are in agreement with the certified values and $\mathrm{Ru}$, Ir and Os agree well with reported values (Meisel et al. 2003).

The recovery of $\mathrm{Au}$ was only about $80 \%$ when Te-coprecipitation technique was used for pre-concentration. In this study, the solution was heated to boil for about $1 \mathrm{~h}$ after the addition of $\mathrm{SnCl}_{2}$ to increase the recoveries of PGE and Au (Amosse 1998), and the standard solution was prepared same as the procedure of sample preparation described above. Thus, the recoveries of $\mathrm{Au}$ for the standard and samples are nearly identical. 
Table 2 Blank (ng) and analytical results $(\mathrm{ng} / \mathrm{g})$ of reference materials, BCR-723

Averge $^{l}$ sample was directly digested, Averge ${ }^{2}$ sample was ignited before digested

\begin{tabular}{|c|c|c|c|c|c|}
\hline \multirow[t]{2}{*}{ Elements } & \multirow[t]{2}{*}{ Blank } & \multicolumn{4}{|l|}{ BCR-723 } \\
\hline & & $\begin{array}{l}\text { Averge }^{1} \\
(N=3)\end{array}$ & $\begin{array}{l}\text { Averge }^{2} \\
(N=3)\end{array}$ & $\begin{array}{l}\text { Meisel } \\
\text { et al. (2003) }\end{array}$ & Certified \\
\hline Os & 0.005 & 0.55 & 0.59 & 0.46 & \\
\hline $\mathrm{Ir}$ & 0.025 & 0.28 & 0.31 & 0.53 & \\
\hline $\mathrm{Ru}$ & 0.017 & 1.17 & 1.08 & 0.85 & \\
\hline $\mathrm{Rh}$ & 0.026 & 10.2 & 10.5 & 11.8 & 12.8 \\
\hline $\mathrm{Pt}$ & 0.18 & 79.9 & 74.7 & 82.4 & 81.3 \\
\hline $\mathrm{Pd}$ & 0.37 & 5.31 & 5.05 & 4.52 & 6.0 \\
\hline
\end{tabular}

\section{Results and discussion}

The background values

To identify the elevated PGE contents through anthropogenic contributions in environmental samples, a local natural background level is required to establish as a reference point. Therefore, the local uncontaminated soils can be considered as the background values. As listed in Table 3, the background values have PGE abundances generally similar to those reported for the Upper Continental Crust (Wedepohl 1995; Peucker-Ehrenbrink and Jahn 2001) and the crust levels in eastern part of China (Chi and Yan 2006).

Platinum, palladium and rhodium

The PGE concentrations of road dusts and roadside soils from Guangzhou, Shenzhen and Hong Kong are given in Table 4. The road dusts and roadside soils have Pt, Pd and $\mathrm{Rh}$ contents significantly higher than the background values. The road dusts contain the highest PGE concentrations (Table 4), suggesting inputs from automobile catalyst system. Pt, Pd and Rh concentrations of the road dusts from Hong Kong range from 12.1 to $187,12.4$ to $287,1.03$ to 29.4, respectively. Those from Shenzhen range from 14.1 to $178,33.8$ to $514,4.9$ to $53 \mathrm{ng} / \mathrm{g}$, respectively, those from Guangzhou range from 4.66 to $48.2,13.0$ to $554,2.14$ to $14.5 \mathrm{ng} / \mathrm{g}$, respectively. These values are comparable with those reported for other countries (Lesniewska et al. 2004). The large range of $\mathrm{Pt}, \mathrm{Pd}$ and $\mathrm{Rh}$ contents in the dust samples from these three cities may be caused by different traffic densities and sample spots from different distance away from the road as reported previously (Jarvis et al. 2001; Morcelli et al. 2005; Whiteley and Murray 2005). All the soil samples have Pt, Pd and Rh much lower than the dust samples. This may also reflect the longer transportation distance of PGE to the soil samples rather than the dust samples. Pan et al. (2009) reported Pt, Pd and Rh concentrations in soil samples from five cities in China (Beijing, Guangzhou, Hong Kong, Macao and Qingdao). The highest values are $160 \mathrm{ng} / \mathrm{g} \mathrm{Pt}, 107 \mathrm{ng} / \mathrm{g} \mathrm{Pd}$ and $34.5 \mathrm{ng} / \mathrm{g}$ $\mathrm{Rh}$ for the Hong Kong soils which are higher than the soil samples but lower than the dust samples in this work. Wang and Sun (2009) also reported Pt and Pd concentrations $(2.9$ and $2.8 \mathrm{ng} / \mathrm{g})$ in roadside soils from Xuzhou, China. Their values are lower than those for the Pearl River Delta region reported here.

Automobile catalysts mainly contain Pt, Pd and Rh, and may release into the environment through exhausting system. Thus, these three elements show positive correlations for the roadside dusts and soils samples. Our data indicate

Table 3 PGE abundance (ng/g) for upper crust and local background values

\begin{tabular}{|c|c|c|c|c|c|c|}
\hline \multirow[t]{2}{*}{ Elements } & \multicolumn{3}{|l|}{ Upper crust } & \multirow{2}{*}{$\begin{array}{l}\text { Uncontaminated soil } \\
\text { (Guangzhou) } \\
\text { This work (averge), } \\
n=2\end{array}$} & \multirow{2}{*}{$\begin{array}{l}\text { Uncontaminated soil } \\
\text { (Shenzhen) } \\
\text { This work (averge), } \\
n=2\end{array}$} & \multirow{2}{*}{$\begin{array}{l}\text { Uncontaminated soil } \\
\text { (Hong Kong) } \\
\text { This work (averge), } \\
n=3\end{array}$} \\
\hline & $\begin{array}{l}\text { Wedepohl } \\
\text { (1995) }\end{array}$ & $\begin{array}{l}\text { Peucker-Ehrenbrink } \\
\text { and Jahn (2001) }\end{array}$ & $\begin{array}{l}\text { Chi and Yan } \\
\text { (2006) }\end{array}$ & & & \\
\hline Os & 0.05 & 0.031 & 0.046 & 0.023 & 0.026 & 0.013 \\
\hline $\mathrm{Ir}$ & 0.05 & 0.022 & 0.017 & 0.005 & 0.011 & 0.009 \\
\hline $\mathrm{Ru}$ & 0.1 & 0.21 & 0.028 & 0.030 & 0.031 & 0.015 \\
\hline $\mathrm{Rh}$ & 0.06 & & 0.023 & 0.012 & 0.036 & 0.011 \\
\hline $\mathrm{Pt}$ & 0.4 & 0.51 & 0.26 & 0.20 & 0.31 & 0.33 \\
\hline $\mathrm{Pd}$ & 0.4 & 0.52 & 0.28 & 0.44 & 0.62 & 0.87 \\
\hline $\mathrm{Au}$ & 2.5 & & & 0.55 & 1.35 & 1.01 \\
\hline
\end{tabular}




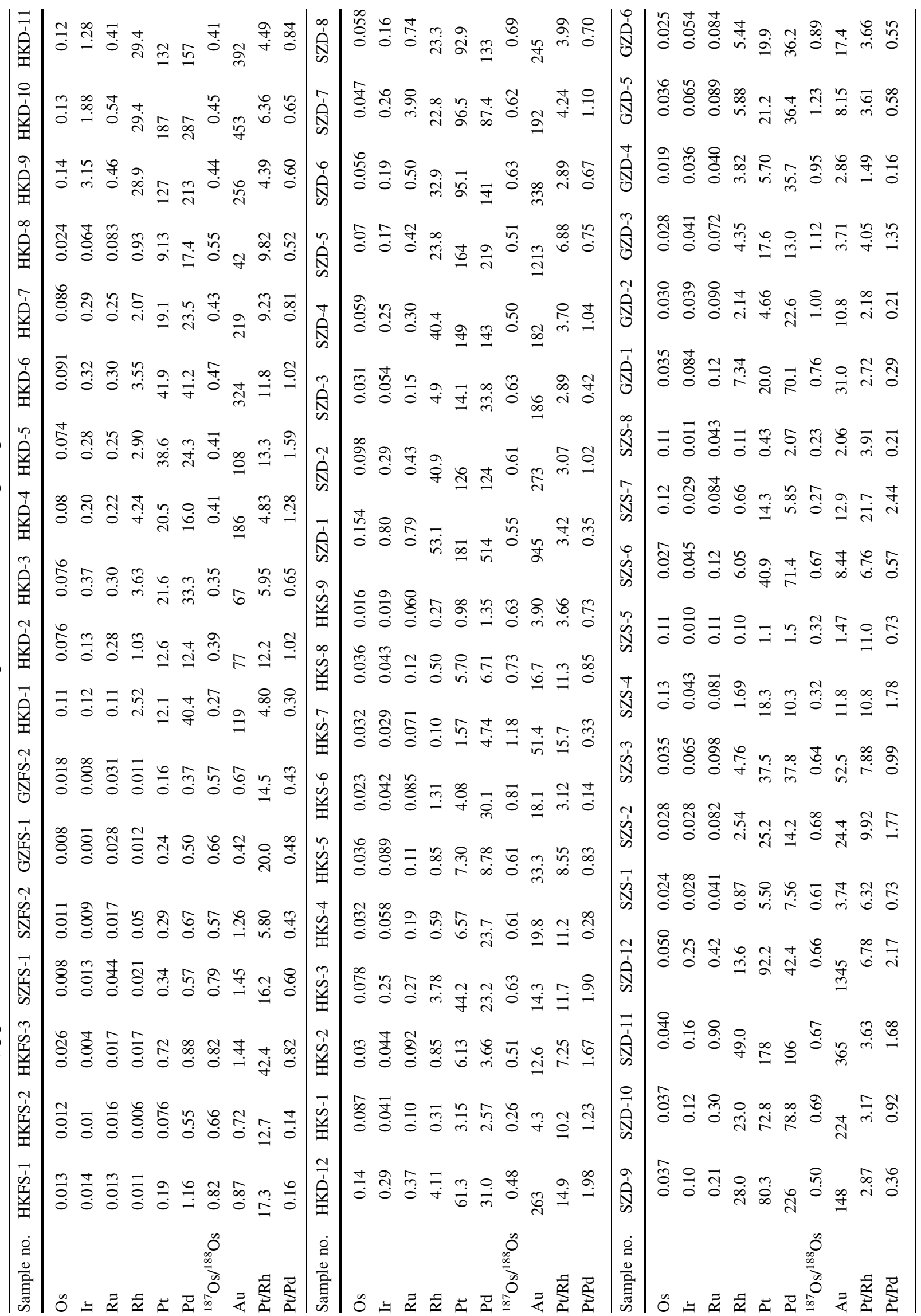




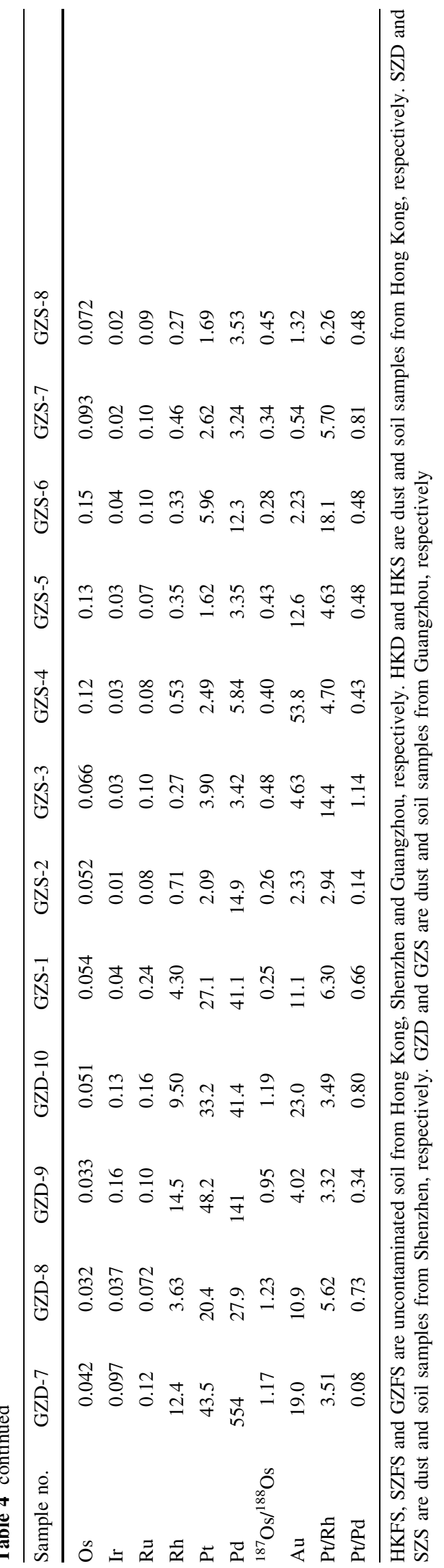

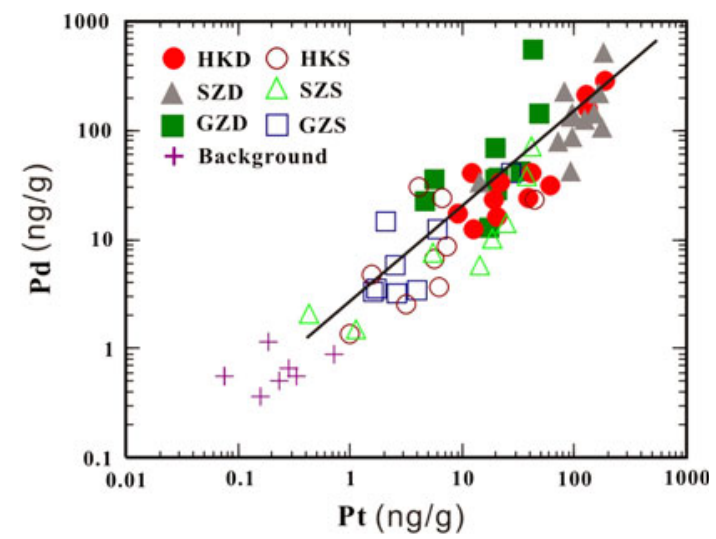
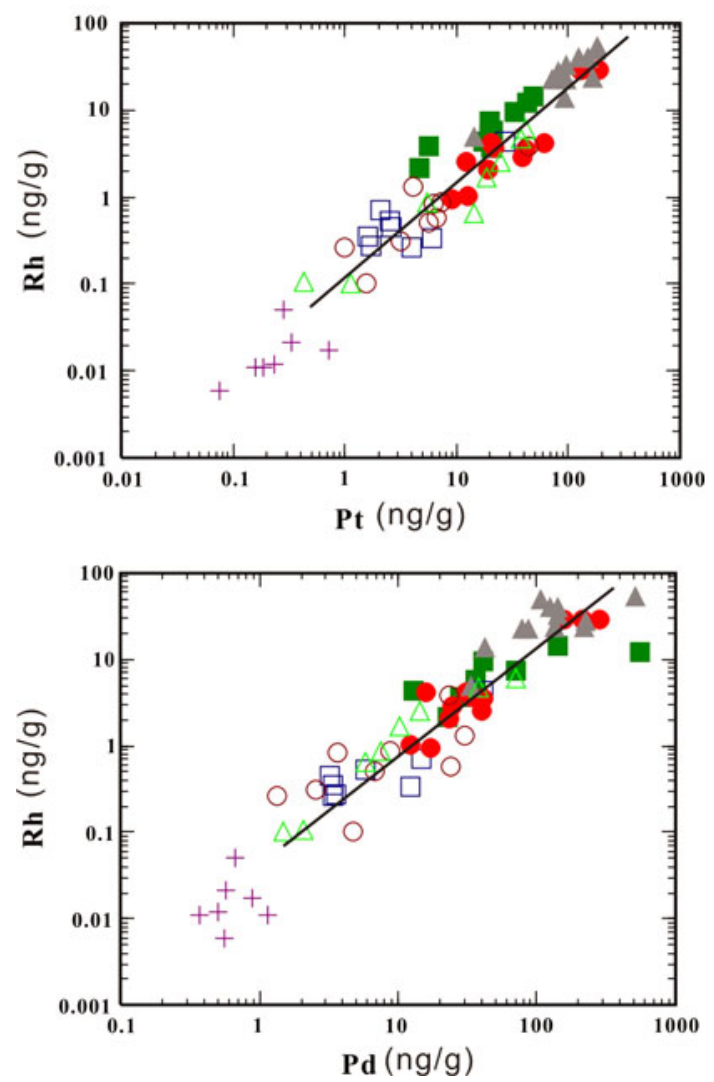

Fig. 2 Plots of Pt versus $\mathrm{Pd}, \mathrm{Pt}$ versus $\mathrm{Rh}, \mathrm{Pd}$ versus $\mathrm{Rh}$ and $\mathrm{Pt} / \mathrm{Rh}$ versus $\mathrm{Rh}$ for the samples from Pearl River Delta region

that there are clearly positive correlations between Pt and $\mathrm{Pd}, \mathrm{Pt}$ and Rh and Pd and Rh (Fig. 2) for the samples from three cities in the Pearl River Delta region, again consistent with automobile catalyst sources. The $\mathrm{Pt} / \mathrm{Pd}$ ratios of the dust samples from Shenzhen (0.35-2.17, with an average of 0.93) are comparable with that in Hong Kong (0.3-1.98, with an average of 0.94 ; Table 4 ). The $\mathrm{Pt} / \mathrm{Pd}$ ratios of the dust samples from Guangzhou (0.21-1.35, with an average of 0.51) are lower than those from Shenzhen and Hong Kong. The $\mathrm{Pt} / \mathrm{Pd}$ ratios in our samples have smaller range than those reported previously (0.3-7.3) (Pan et al. 2009). $\mathrm{The} \mathrm{Pt} / \mathrm{Rh}$ ratios of the dust samples from Hong Kong 
(4.4-14.9, with an average of 8.51) are clearly higher than those from Shenzhen (2.87-10.8, average 3.96) and Guangzhou (1.49-5.62, average 3.37) (Table 4), but similar to those reported previously by Pan et al. (2009). The $\mathrm{Pt} / \mathrm{Rh}$ and $\mathrm{Pt} / \mathrm{Pd}$ ratios of our samples are similar to those reported previously for urban dusts and soils (Gomez et al. 2002; Lesniewska et al. 2004), within the ranges of $\mathrm{Pt} / \mathrm{Rh}$ 5-16 and Pt/Pd 1-2.5 (Ely et al. 2001). They are within the range in commonly used gasoline catalysts $(\mathrm{Pt} / \mathrm{Rh}=5)$ (Palacios et al. 2000). The different $\mathrm{Pt} / \mathrm{Pd}$ and $\mathrm{Pt} / \mathrm{Rh}$ ratios for the samples from Guangzhou, Shenzhen and Hong Kong appear to reflect different automobile catalyst systems used in Hong Kong and mainland China.

Ruthenium and iridium

Until present, other than Pt, Pd and Rh, only limited studies have been reported for automobile catalyst-related $\mathrm{Ru}$ and Ir in environmental samples (Muller and Heumann 2000; Ely et al. 2001; Fritsche and Meisel 2004; Rauch et al. 2004a, b, 2006). Iridium has been used in some new diesel catalysts together with Pt (Palacios et al. 2000). Muller and Heumann (2000) reported elevated Ir and Ru concentrations in roadside soils and tunnel dust samples. They found that $\mathrm{Ru}$ concentrations in the samples are related to the distance from roads. Rauch et al. (2004a) reported elevated Ir and $\mathrm{Ru}$ contents in sediments in an urban lake near Boston, and suggested that Ir is present as catalyst component or impurity and $\mathrm{Ru}$ is present as catalyst impurity. Ely et al. (2001) also reported elevated Ir concentrations in soils, and suggested the Ir is probably present as an impurity in automobile catalysts.

The Ir and Ru concentrations of our samples are clearly higher than the background values and Upper Continental Crust (Wedepohl 1995; Peucker-Ehrenbrink and Jahn 2001; Chi and Yan 2006; Table 4; Fig. 3). There are clearly positive correlations between Pt and Ir, Pt and $\mathrm{Ru}$, and $\mathrm{Ir}$ and $\mathrm{Ru}$ in our samples, except no correlations between Pt and Ru, and Ir and Ru in Guangzhou (Fig. 3). We suggest that the elevated Ir and $\mathrm{Ru}$ in soil and dust samples from the Pearl River Delta region are related to emission of automobile catalyst in which these elements occur as impurities.

\section{Osmium}

During Earth's mantle-crust differentiation, Os is compatible and Re is incompatible. As a result, crustal materials have very low Os abundance and high Re/Os ratios which yield extremely radiogenic Os isotopic signatures with high ${ }^{187} \mathrm{Os} /{ }^{188} \mathrm{Os}$ ratio in upper crust materials (Koide et al. 1991; Esser and Turekian 1993). The ${ }^{187} \mathrm{Os} /{ }^{188} \mathrm{Os}$ ratio of primitive mantle is $0.1290 \pm 0.0009$ (Meisel et al.
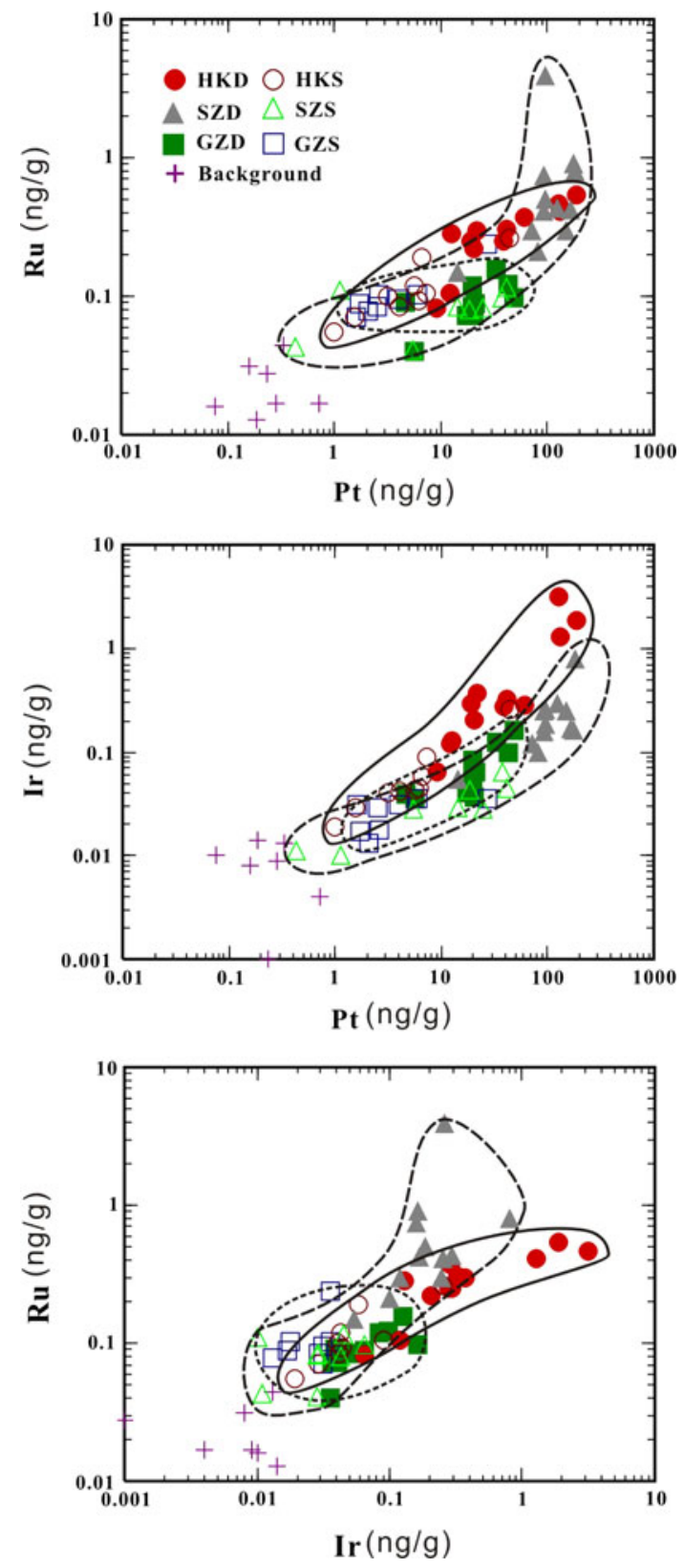

Fig. 3 Plots of Pt versus Ir and Pt versus Ru for the samples from Pearl River Delta region

1996). This value is significantly lower than the crustal value. A small anthropogenic input of Os that is originally derived from mantle may reduce the ${ }^{187} \mathrm{Os} /{ }^{188} \mathrm{Os}$ ratios. Elevated Os concentrations have been found in environmental samples and are thought to be the result of emission from automobile catalysts in which Os occurs as an impurity (Fritsche and Meisel 2004; Poirier and Gariepy 2005; Rauch et al. 2005, 2006). In this study, almost all samples have higher Os contents and lower ${ }^{187} \mathrm{Os} /{ }^{188} \mathrm{Os}$ ratios than the background values (Fig. 4; Table 4), indicating an anthropogenic source of Os that originally 

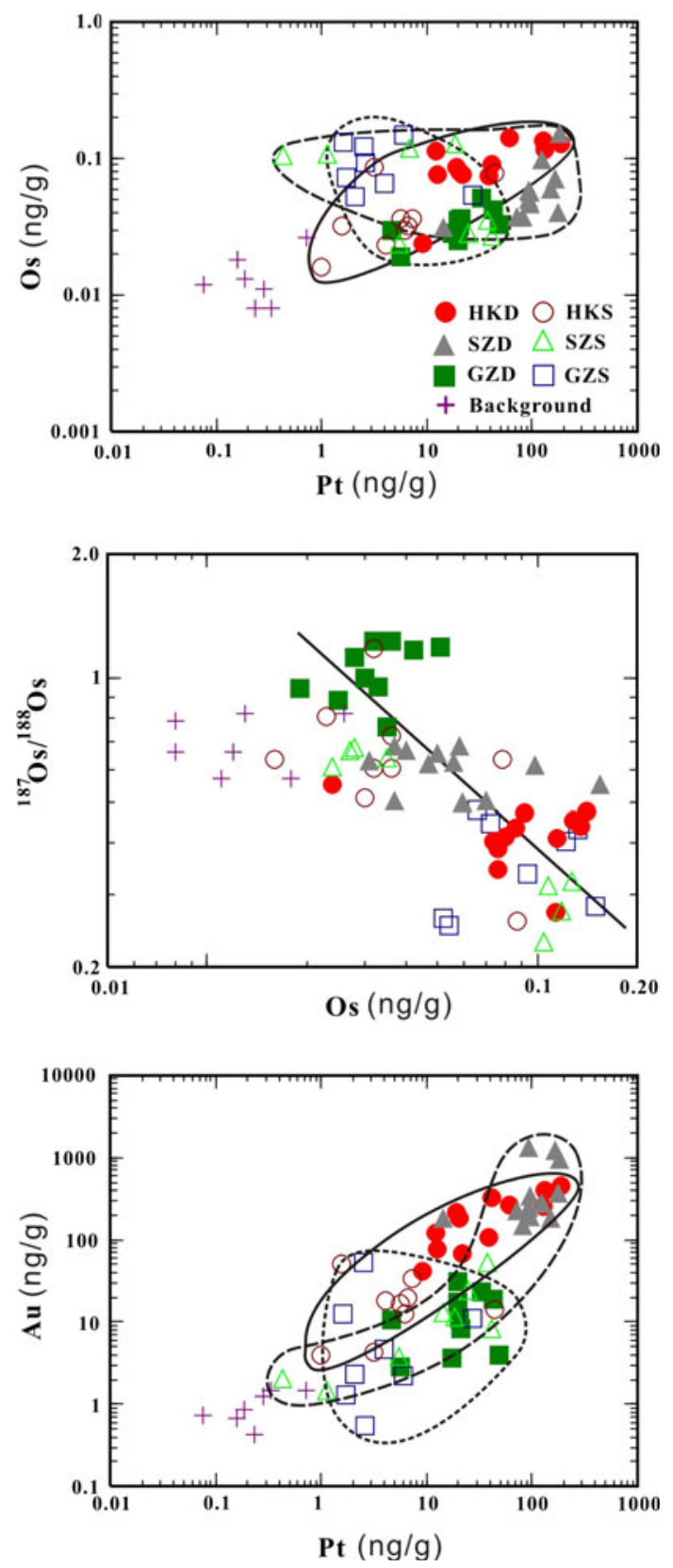

Fig. 4 Plots of Pt versus Os, Pt versus $\mathrm{Au}$ and ${ }^{187} \mathrm{Os} /{ }^{188}$ Os versus Os for the samples from Pearl River Delta region

derived from mantle. Our results support the interpretation that Os is an impurity in the automobile catalysts.

When Os is emitted from the high temperature automobile engine, it may be oxidized to volatile $\mathrm{OsO}_{4}$, and therefore may be transferred further than other PGE particles (Poirier and Gariepy 2005). Samples from Hong Kong, Shenzhen and Guangzhou show no correlation between $\mathrm{Pt}$ and $\mathrm{Os}$ in both soil and dust samples (Fig. 4). We suggest that this is because volatile $\mathrm{OsO}_{4}$ has been transported farther away from its source than other PGE.

\section{Gold}

Few studies are available on $\mathrm{Au}$ contamination by the emissions from automobile catalysts. Eisler (2004) reported up to $440 \mathrm{ng} / \mathrm{g} \mathrm{Au}$ in atmospheric dusts collected from heavy traffic roads in Germany. Hooda et al. (2007) reported relatively high Au concentrations (up to $18 \mathrm{ng} / \mathrm{g}$ ) in soils which are higher than the crustal average $(5 \mathrm{ng} / \mathrm{g})$, suggesting an anthropogenic source. It should be noted that $\mathrm{Au}$ is an effective catalyst and recent advances in technology allow its use in automobile catalytic converters, offering a cost-effective alternative to PGE to oxidate carbon monoxide (Haruta et al. 1993; Haruta 1997a, b; Mellor et al. 2002). The significant feature of gold-based three-way catalyst in gasoline and diesel applications is the low temperature oxidation of carbon monoxide, where the catalysts display activity as low as $-70^{\circ} \mathrm{C}$ (Mellor et al. 2002).

The contents of $\mathrm{Au}$ in dusts from Hong Kong (42-453 ng/g, average $209 \mathrm{ng} / \mathrm{g}$ ) and Shenzhen (148$1345 \mathrm{ng} / \mathrm{g}$, average $471 \mathrm{ng} / \mathrm{g}$ ) are much higher than soils (average 19.4 and $14.7 \mathrm{ng} / \mathrm{g}$ ) and the background values (average $0.98 \mathrm{ng} / \mathrm{g}$ ). Dust samples from Hong Kong and Shenzhen show clearly positive correlation between $\mathrm{Au}$ and Pt (Fig. 4). Because these samples were collected from the commercial streets and highways with no industrial input, the anomalies are likely related to contamination from automobile catalysts. The contents of $\mathrm{Au}$ in all the samples from Guangzhou (average $12.2 \mathrm{ng} / \mathrm{g}$ ) are much lower than those from Shenzhen and Hong Kong and show no correlations between $\mathrm{Pt}$ and $\mathrm{Au}$ (Fig. 4). The similarity between Shenzhen and Hong Kong may have caused by the frequent shuttle traffic between these two cities. The difference between Guangzhou and Hong Kong may reflect the different automobile catalyst systems between mainland China and Hong Kong.

\section{Conclusions}

This study presents the results of PGE and Au in road dusts and roadside soils collected from three major cities in Pearl River Delta region, South China. The proposed low procedure blank and effective Carius tube technique together have improved the precision of PGE and Au determination in environmental samples, especially for the uncontaminated soil samples for establishing the background values.

The background values of PGE and Au in the study area were established. The highest levels of $\mathrm{Pt}, \mathrm{Rh}$ and $\mathrm{Pd}$ were found in road dusts and are due to contamination from automobile catalyst. Similar Pt/Pd ratios for the samples from Hong Kong, Guangzhou and Shenzhen reflect similar $\mathrm{Pt} / \mathrm{Pd}$ ratios in the automobile catalysts used in these cities. 
The $\mathrm{Pt} / \mathrm{Rh}$ ratios of dust samples from Hong Kong are higher than those from Guangzhou and Shenzhen, reflecting the different automobile catalyst system between Hong Kong and mainland China. The elevated levels of Ru, Ir and Os in road dust and roadside soil samples are possibly related to the impurity of these elements in the automobile catalysts. Anomalous high concentrations of Au in the dust samples from Shenzhen and Hong Kong may also be related to emission from automobile catalyst systems.

Acknowledgments This study was supported by "CAS Hundred Talents" Project from Chinese Academy of Sciences to Qi Liang (KZCX2-YW-BR-09), the National Natural Science Foundation of China (NSFC 40773070), and the Research Grant Council of Hong Kong (HKU7057/05P). We thank Dr. D. C. Gregoire from the Geological Survey of Canada for providing us the spike solutions of ${ }^{190} \mathrm{Os},{ }^{101} \mathrm{Ru},{ }^{105} \mathrm{Pd},{ }^{193} \mathrm{Ir}$, and ${ }^{194} \mathrm{Pt}$.

Open Access This article is distributed under the terms of the Creative Commons Attribution Noncommercial License which permits any noncommercial use, distribution, and reproduction in any medium, provided the original author(s) and source are credited.

\section{References}

Amosse J (1998) Determination of platinum-group elements and gold in geological matrices by inductively coupled plasma-mass spectrometry (ICP-MS) after separation with selenium and tellurium carriers. Geostand Geoanal Res 22:93-102

Barbante C, Veysseyre A, Ferrari C, Van de Velde K, Morel C, Capodaglio G, Cescon P, Scarponi G, Boutron C (2001) Greenland snow evidence of large scale atmospheric contamination for platinum, palladium, and rhodium. Environ Sci Technol 35:835-839

Barefoot RR (1997) Determination of platinum at trace levels in environmental and biological materials. Environ Sci Technol 31:309-314

Chi QH, Yan MC (2006) Platinum-group element abundances in crust, rocks and sediments. Geochimica 35:461-471 (in Chinese with English abstract)

Cicchella D, Fedele L, De Vivo B, Albanese S, Lima A (2008) Platinum group element distribution in the soils from urban areas of the Campania region (Italy). Geochem Explor Environ Anal $8: 31-40$

Eisler R (2004) Gold concentrations in abiotic materials, plants, and animals: a synoptic review. Environ Monit Assess 90:73-88

Ek KH, Morrison GM, Lindberg P, Rauch S (2004) Comparative tissue distribution of metals in birds in Sweden using ICP-MS and laser ablation ICP-MS. Arch Environ Contam Toxicol 47:259-269

Ely JC, Neal CR, Kulpa CF, Schneegurt MA, Seidler JA, Jain JC (2001) Implications of platinum-group element accumulation along US roads from catalytic-converter attrition. Environ Sci Technol 35:3816-3822

Esser BK, Turekian KK (1993) The osmium isotopic composition of the continental-crust. Geochim Cosmochim Acta 57:30933104

Fang J, Jiang Y, Yan XP, Ni ZM (2005) Selective quantification of trace palladium in road dusts and roadside soils by displacement solid-phase extraction online coupled with electrothermal atomic absorption spectrometry. Environ Sci Technol 39:288-292
Fritsche J, Meisel T (2004) Determination of anthropogenic input of $\mathrm{Ru}, \mathrm{Rh}, \mathrm{Pd}, \mathrm{Re}, \mathrm{Os}$, Ir and Pt in soils along Austrian motorways by isotope dilution ICP-MS. Sci Total Environ 325:145-154

Gomez B, Palacios MA, Gomez M, Sanchez JL, Morrison G, Rauch S, McLeod C, Ma R, Caroli S, Alimonti A, Petrucci F, Bocca B, Schramel P, Zischka M, Petterson C, Wass U (2002) Levels and risk assessment for humans and ecosystems of platinum-group elements in the airborne particles and road dust of some European cities. Sci Total Environ 299:1-19

Haruta M (1997a) Gold as a low-temperature oxidation catalyst: factors controlling activity and selectivity. In: Proceedings of the 3rd world congress on oxidation catalysis. Stud Surf Sci Catal, pp 123-134

Haruta M (1997b) Size- and support-dependency in the catalysis of gold. Catal Today 36:153-166

Haruta M, Tsubota S, Kobayashi T, Kageyama H, Genet MJ, Delmon B (1993) Low-temperature oxidation of Co over gold supported on $\mathrm{TiO}_{2}$, alpha- $\mathrm{Fe}_{2} \mathrm{O}_{3}$, and $\mathrm{Co}_{3} \mathrm{O}_{4}$. J Catal 144:175-192

Hooda PS, Miller A, Edwards A (2007) The distribution of automobile catalysts-cast platinum, palladium and rhodium in soils adjacent to roads and their uptake by grass. Sci Total Environ 384:384-392

Hooda PS, Miller A, Edwards AC (2008) The plant availability of auto-cast platinum group elements. Environ Geochem Health 30:135-139

Jarvis KE, Parry SJ, Piper JM (2001) Temporal and spatial studies of autocatalyst-derived platinum, rhodium, and palladium and selected vehicle derived trace elements in the environment. Environ Sci Technol 35:1031-1036

Jensen KH, Rauch S, Morrison GM, Lindberg P (2002) Platinum group elements in the feathers of raptors and their prey. Arch Environ Contam Toxicol 42:338-347

Kan SF, Tanner PA (2004) Determination of platinum in roadside dust samples by dynamic reaction cell-inductively coupled plasma-mass spectrometry. J Anal Atom Spectrom 19:639-643

Kan SF, Tanner PA (2005) Platinum concentrations in ambient aerosol at a coastal site in South China. Atmos Environ 39:26252630

Koide M, Goldberg ED, Niemeyer S, Gerlach D, Hodge V, Bertine KK, Padova A (1991) Osmium in marine-sediments. Geochim Cosmochim Acta 55:1641-1648

Lesniewska BA, Godewska-Zylkiewicz B, Bocca B, Caimi S, Caroli S, Hulanicki A (2004) Platinum, palladium and rhodium content in road dust, tunnel dust and common grass in Bialystok area (Poland): a pilot study. Sci Total Environ 321:93-104

Meisel T, Walker RJ, Morgan JW (1996) The osmium isotopic composition of the Earth's primitive upper mantle. Nature 383:517-520

Meisel T, Fellner N, Moser J (2003) A simple procedure for the determination of platinum group elements and rhenium $(\mathrm{Ru}, \mathrm{Rh}$, $\mathrm{Pd}, \mathrm{Re}, \mathrm{Os}$, Ir and Pt) using ID-ICP-MS with an inexpensive on-line matrix separation in geological and environmental materials. J Anal Atom Spectrom 18:720-726

Mellor JR, Palazov A, Grigorova BS, Greyling JF, Reddy K, Letsoalo MP, Marsh JH (2002) The application of supported gold catalysts to automotive pollution abatement. Catal Today $72: 145-156$

Moldovan M, Palacios MA, Gomez MM, Morrison G, Rauch S, McLeod C, Ma R, Caroli S, Alimonti A, Petrucci F, Bocca B, Schramel P, Zischka M, Pettersson C, Wass U, Luna M, Saenz JC, Santamaria J (2002) Environmental risk of particulate and soluble platinum group elements released from gasoline and diesel engine catalytic converters. Sci Total Environ 296:199208

Morcelli CPR, Figueiredo AMG, Sarkis JES, Enzweiler J, Kakazu M, Sigolo JB (2005) PGEs and other traffic-related elements in 
roadside soils from Sao Paulo, Brazil. Sci Total Environ 345:8191

Muller M, Heumann KG (2000) Isotope dilution inductively coupled plasma quadrupole mass spectrometry in connection with a chromatographic separation for ultra trace determinations of platinum group elements ( $\mathrm{Pt}, \mathrm{Pd}, \mathrm{Ru}, \mathrm{Ir})$ in environmental samples. Fresenius J Anal Chem 368:109-115

Palacios M, Gomez MM, Moldovan M, Morrison G, Rauch S, McLeod C, Ma R, Laserna J, Lucena P, Caroli S, Alimonti A, Petrucci F, Bocca B, Schramel P, Lustig S, Zischka M, Wass U, Stenbom B, Luna M, Saenz JC, Santamaria J (2000) Platinumgroup elements: quantification in collected exhaust fumes and studies of catalyst surfaces. Sci Total Environ 257:1-15

Pan SH, Zhang G, Sun YL, Chakraborty P (2009) Accumulating characteristics of platinum group elements (PGE) in urban environments, China. Sci Total Environ 407:4248-4252

Peucker-Ehrenbrink B, Jahn BM (2001) Rhenium-osmium isotope systematics and platinum group element concentrations: Loess and the upper continental crust. Geochem Geophys Geosys 2(10), 1061. doi:10.1029/2001GC000172

Poirier A, Gariepy C (2005) Isotopic signature and impact of car catalysts on the anthropogenic osmium budget. Environ Sci Technol 39:4431-4434

Qi L, Zhou MF (2008) Determination of platinum-group elements in OPY-1: comparison of results using different digestion techniques. Geostand Geoanal Res 32:377-387

Qi L, Zhou MF, Wang CY (2004) Determination of low concentrations of platinum group elements in geological samples by IDICP-MS. J Anal Atom Spectrom 19:1335-1339

Rauch S, Hemond HF, Peucker-Ehrenbrink B (2004a) Recent changes in platinum group element concentrations and osmium isotopic composition in sediments from an urban lake. Environ Sci Technol 38:396-402

Rauch S, Hemond HF, Peucker-Ehrenbrink B (2004b) Source characterisation of atmospheric platinum group element deposition into an ombrotrophic peat bog. J Environ Monit 6:335-343

Rauch S, Hemond HF, Peucker-Ehrenbrink B, Ek KH, Morrison GM (2005) Platinum group element concentrations and osmium isotopic composition in urban airborne particles from Boston, Massachusetts. Environ Sci Technol 39:9464-9470

Rauch S, Peucker-Ehrenbrink B, Molina LT, Molina MJ, Ramos R, Hemond HF (2006) Platinum group elements in airborne particles in Mexico City. Environ Sci Technol 40:7554-7560
Ravindra K, Bencs L, Van Grieken R (2004) Platinum group elements in the environment and their health risk. Sci Total Environ 318:1-43

Sures B, Zimmermann S (2007) Impact of humic substances on the aqueous solubility, uptake and bioaccumulation of platinum, palladium and rhodium in exposure studies with Dreissena polymorpha. Environ Pollut 146:444-451

Wang XS, Qin Y (2007) Some characteristics of the distribution of heavy metals in urban topsoil of Xuzhou, China. Environ Geochem Health 29:11-19

Wang XS, Sun C (2009) Pt and Pd concentrations and source in urban roadside soils from Xuzhou, China. Environ Geol 56:1129-1133

Wang XS, Qin Y, Sang SX (2005) Accumulation and sources of heavy metals in urban topsoils: a case study from the city of Xuzhou, China. Environ Geol 48:101-107

Wang J, Zhu RH, Shi YZ (2007) Distribution of platinum group elements in road dust in the Beijing metropolitan area, China. J Environ Sci China 19:29-34

Wedepohl KH (1995) The composition of the continental-crust. Geochim Cosmochim Acta 59:1217-1232

Whiteley JD, Murray F (2005) Autocatalyst-derived platinum, palladium and rhodium (PGE) in infiltration basin and wetland sediments receiving urban runoff. Sci Total Environ 341:199 209

Wichmann H, Anquandah GAK, Schmidt C, Zachmann D, Bahadir MA (2007) Increase of platinum group element concentrations in soils and airborne dust in an urban area in Germany. Sci Total Environ 388:121-127

Zechmeister HG, Hagendorfer H, Hohenwallner D, Hanus-Illnar A, Riss A (2006) Analyses of platinum group elements in mosses as indicators of road traffic emissions in Austria. Atmos Environ 40:7720-7732

Zimmermann S, Baumann U, Taraschewski H, Sures B (2004) Accumulation and distribution of platinum and rhodium in the European eel Anguilla anguilla following aqueous exposure to metal salts. Environ Pollut 127:195-202

Zimmermann S, Messerschmidt J, von Bohlen A, Sures B (2005) Uptake and bioaccumulation of platinum group metals (Pd, Pt, $\mathrm{Rh})$ from automobile catalytic converter materials by the zebra mussel (Dreissena polymorpha). Environ Res 98:203-209 